\title{
Anti-thrombin III, Protein C, and Protein S deficiency in acute coronary syndrome
}

\author{
Dasnan Ismail*, S Harun*, Idrus Alwi*, Karmel L Tambunan**, Shufrie Effendy**
}

\begin{abstract}
Abstrak
Akhir perjalanan yang sangat sering ditemukan pada sebagian besar penyakit jantung koroner adalah oklusi pembuluh darah koroner. Pada keadaan normal, antithrombin III (AT III), protein C dan protein S sebagai kofaktor protein C aktif, merupakan antikoagulan alami (pengontrol hemostasis) yang berperan menyeimbangkan aktivitas prokoagulan (keseimbangan kompleks antithrombin-thrombin), untuk mencegah terjadinya trombosis. Dalam keadaan tak seimbang, antikoagulan alami dan prokoagulan dapat menyebabkan tejadinya trombosis. Dilakukan penelitian pada tigapuluh subyek dengan sindrom koroner akut (SKA) untuk melihat angka kejadian defisiensi antithrombin III (AT III), protein C dan protein S, dan hasilnya dibandingkan dengan kelompok kontrol. Pada pasien SKA, distribusi frekuensi AT-III dengan aktivitas < $75 \%$ adalah 23,3\% (7 dari 30), di mana hanya ditemukan $6.7 \%$ (2 dari 30) pada kelompok kontrol. Tidak ditemukan defisiensi protein C pada 30 subyek kelompok kontrol, sedangkan pada SKA di mana aktivitas < $70 \%$ ditemukan 13.3\% (4 dari 30). Lima puluh persen (15 dari 30) subyek kelompok kontrol mengalami defisiensi aktivitas protein $S$, sedangkan pada SKA dengan aktivitas protein $S<70 \%$ ditemukan 73,3 \% (22 dari 30). Pada analisis regresi linier, koefisien determinan defisiensi aktivitas AT-III untuk terjadinya SKA adalah 13,25 \% dan koefisien determinan defisiensi aktivitas protein C untuk terjadinya SKA adalah 9,06\%, cut-off point aktivitas AT III tanpa defisiensi protein $S$ yang diperkirakan untuk terjadinya SKA adalah $45 \%$. Pada analisis diskriminan, defisiensi aktivitas protein C mempunyai estimasi risiko untuk terjadinya SKA sebesar 4,5 kali dibandingkan tanpa defisiensi protein $C$, dan defisiensi aktivitas AT III mempunyai estimasi risiko untuk terjadinya SKA sebesar 3,5 kali dibandingkan tanpa defisensi AT III. pada regresi logistik binary, defisiensi aktivitas protein S hanya merupakan faktor penguat defisiensi aktivitas ATIII untuk terjadinya SKA. Defisierisi protein C dan AT III dapat merupakan faktor pemicu untuk terjadinya SKA, di mana koefisien determinan untuk terjadinya SKA adalah sebesar 9,06 dan 13,25\%. Aktivitas protein C rendah memberikan risiko lebih tinggi untuk terjadinya SKA dibandingkan aktivitas AT III rendah. Defisiensi protein S merupakan faktor penguat defisiensi faktor AT III untuk terjadinya SKA. Cut-off point aktivitas AT III tanpa defisiensi protein S untuk terjadinya penyakit satu pembuluh adalah $45 \%$ dan untuk penyakit tiga pembuluh adalah 9,05\%. (Med J Indones 2002; 11: 87-92)
\end{abstract}

\begin{abstract}
The final most common pathway for the majority of coronary artery disease is occlusion of a coronary vessel. Under normal conditions, antithrombin III (AT III), protein $C$, and protein $S$ as an active protein $C$ cofactor, are natural anticoagulants (hemostatics control) that balances procoagulant activity (thrombin antithrombin complex balance) to prevent thrombosis. If the condition becomes unbalanced, natural anticoagulants and the procoagulants can lead to thrombosis. Thirty subjects with acute coronary syndrome ( ACS ) were studied for the incidence of antithrombin III (AT III), protein $C$, and protein $S$ deficiencies, and the result were compare to the control group. Among patients with ACS, the frequency of distribution of AT-III with activity $<75 \%$ were $23,3 \%(7$ of 30), and only 6,7\% ( 2 of 30 ) in control subject. No one of the 30 control subject have protein $C$ activity deficient, in ACS with activity $<70 \%$ were $13,3 \%$ ( 4 of 30 ). Fifteen out of the $30(50 \%)$ control subjects had protein $S$ activity deficiency, while protein $S$ deficiency activity $<70 \%$ was found $73,3 \%$ (22 out of 30). On linear regression, the deterministic coefficient of AT-III activity deficiency to the development ACS was $13,25 \%$, and the deterministic coefficient of protein C activity deficient to the development of ACS was $9,06 \%$. The cut-off point for AT-III without protein $S$ deficiency expected to contibute to the development of vessel disease was 45\%. On discriminant analysis, protein $C$ activity deficiency posed a risk for ACS of 4,5 greater than non deficient subjects, and AT-III activity deficiency posed a risk for ACS of 3,5 times greater than non deficient subjects. On binary logistic regression, protein $S$ activity acted only as a reinforcing factor of AT-III activity deficiency in the development of ACS. Protein $C$ and AT III deficiency can trigger ACS, with determinant coefficients of $9,06 \%$ and $13,25 \%$ respectively. Low levels of protein $C$ posed a greater risk of ACS than low levels of AT III. Protein $S$ deficiency was a reinforcing factor on AT-III deficient to development of ACS. The cut-off point of AT-III without protein S deficiency expected to give single vessel disease was 45\%, and 9,5\% for the development of triple vessel disease. (Med J Indones 2002; 11: 87-92)
\end{abstract}

Keywords: acute coronary syndrome, Anti-thrombin III, Protein C, Protein S

\footnotetext{
"Division of Cardiology, Department of Internal Medicine, Faculty of Medicine University of Indonesia / Dr. Cipto Mangunkusumo Hospital, Jakarta, Indonesia

** Division of Hematology-Medical Oncology, Department of Internal Medicine, Faculty of Medicine University of Indonesia/ Dr. Cipto Mangunkusumo Hospital, Jakarta, Indonesia
} 
Coronary artery disease is the leading cause of death in western society, and acute coronary syndrome is a very common manifestation of this disease. In the United States, 1,5 million individuals suffer from acute myocardial infarction per year; $50 \%$ of which are fatal. In Indonesia, based on the National Hold Survey on Health by the Department of Health, Indonesia in 1992, cardiovascular disease was the leading cause of mortality. ${ }^{2}$ Of these coronary thrombotic events, $67 \%$ of patients harbour a coagulation blood protein or platelet defect leading to thrombosis. Fifty percent of these coagulation protein or platelet defects are hereditary, thus emphasizing the importance of defining the presence and type of defect in survivors of acute coronary syndrome. Defining the defect also allows one to optimize antithrombotic therapy for secondary prevention. ${ }^{1}$

The final most common pathway for the majority of coronary artery disease is atherosclerotic plaque instability, rupture, and subsequent thrombus formation, which lead to occlusion of a coronary vessel. ${ }^{3}$ Acute myocardial infarction (MI) and unstable angina pectoris are two components of acute coronary syndrome. Atherosclerosis is a dynamic process where rapid progression may occur in young plaques at the site of intense inflammation. ${ }^{3}$ The inflammation disrupts the endothelium, exposing thrombogenic material that triggers platelet aggregation and intravascular coagulation. 'The interaction of platelets, thrombin, and leukocytes in unstable plaque result in the release of various active products, including matrix degradation molecules, procoagulant factors and protein, cytokines, and growth factors (EDGF, VEGF) that can lead to the formation of an obstructive endovascular thrombus, and to accelerated atherosclerosis. ${ }^{3}$

Under normal conditions, antithrombin III (AT III), protein $\mathrm{C}$, and protein $\mathrm{S}$ as an active protein $\mathrm{C}$ cofactor, are natural anticoagulants (hemostatics control) that balances procoagulant activity (thrombin antithrombin complex balance) to prevent thrombosis. If the condition becomes unbalanced, natural anticoagulants and procoagulants can lead to thrombosis. ${ }^{3,4}$

The role of thrombus formation in the pathogenesis of acute coronary syndrome has been well established. However, comprehensive and systematic studies of the natural coagulation inhibitor are not available in patients with these conditions.

\section{METHODS}

Sample size was calculated using correlation with 95\% confidences two tailed by $90 \%$ power and correlation estimate 0.41 , which is 30 subjects for cases and controls. Cases were subjects with 2 out of 3 clinical criterion for acute myocardial infarction; ${ }^{5}$ typical chest pain, characteristic evolution changes in 12 lead ECG, and significant cardiac enzyme elevation and unstable angina according to Braunwald criteria. ${ }^{6}$ All of the cases showed coronary artery disease on coronary angiography. Controls were subjects who were not detected with ischemic pattern on the treadmill test/electrocardiography, or did not have coronary artery disease on coronary angiography. AT III, protein C, and protein S activity were determined from the chromogenic substrate system using chromotimer machine. Data were analyzed using SPSS 10.0 .1 by discriminant, linier, and binary logistic regression to calculate risk estimate of AT III, protein $C$, and protein $S$ and their interaction to the development of ACS.

\section{RESULT}

\section{Case Summary}

AT-III, protein C, and protein S activity assay was performed on 30 subjects with acute coronary syndrome (ACS) on coronary artery studies, and 30 subjects as control. Among the control group, 20 subjects were not found with ischemic pattern on the treadmill test, two of the control subjects were found with ischemic patterns on the treadmill test but did not have coronary artery disease on coronary angiography, and the rest of them ( 8 subjects) did not show ischaemic/infarction pattern. The distribution of number of vessel disease in the control and cases group is shown in Table 1.

Table 1. Distribution of number of vessel disease in the control and cases group

\begin{tabular}{lcccc}
\hline Sex & Non & Single & Double & Triple \\
\hline Male & $20(66,67 \%)$ & $6(66,67 \%)$ & $5(28,6 \%)$ & $9(64,3 \%)$ \\
Female & $10(33,33 \%)$ & $3(33,33 \%)$ & $2(71,4 \%)$ & $5(35,7 \%)$ \\
\hline
\end{tabular}

The minimum activity of AT-II was $60 \%$ in ACS and $57 \%$ in control group, where the median of AT-III activity was $97 \%$ in the control group, $89 \%$ in subjects with single vessel disease, $92 \%$ in subjects 
with double vessel disease, and $80 \%$ in subjects with triple vessel disease (Figure 1).

The minimum protein $\mathrm{C}$ activity was $7 \%$ in subjects with ACS and $81 \%$ in the control groups. The median protein $C$ activity was $146,5 \%$ in the control group, $135 \%$ in subjects with single vessel disease, $124 \%$ in subjects with double vessel disease, and $110,5 \%$ in subjects with triple vessel disease (Figure 1).

The minimum protein S activity was $20 \%$ in subjects with ACS and $18 \%$ in control groups, where the median of protein $S$ activity was $69,5 \%$ in the control group, $56 \%$ in subjecs with single vessel disease,
$32 \%$ in subjects with double vessel disease, and $61 \%$ in subjects with triple vessel disease (Figure 1).

The frequency of distribution of AT-III, protein C, and protein $S$ according to the number of vessel disease are shown in Table 2. The frequency of distribution of AT-III deficiency $(<75 \%)$ were 7 out of $30(23,3 \%)$ in those with ACS, and only 2 out of 30 $(6,7 \%)$ in the control subjects. None of the 30 control subjects had protein $\mathrm{C}$ deficiency (levels <70\%), while 4 out of $30(13,3 \%)$ subjects with ACS. Fifteen out of $30(50 \%)$ control subjects had protein S deficiency (levels $<70 \%$ ), while 22 out of $30(73,3 \%)$ subjects with ACS had protein S deficiency.

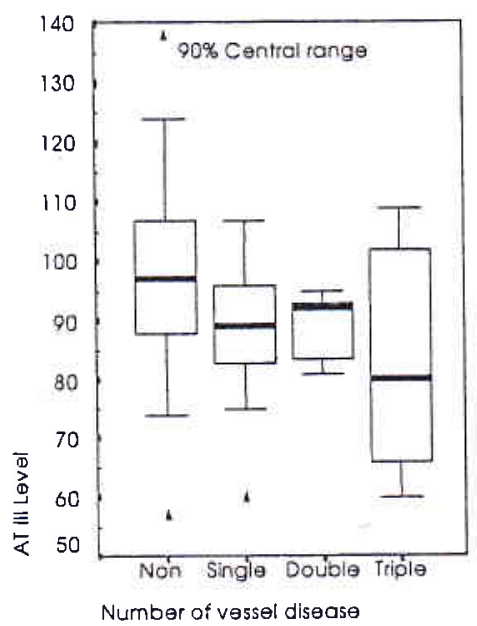

Box-plot AT III

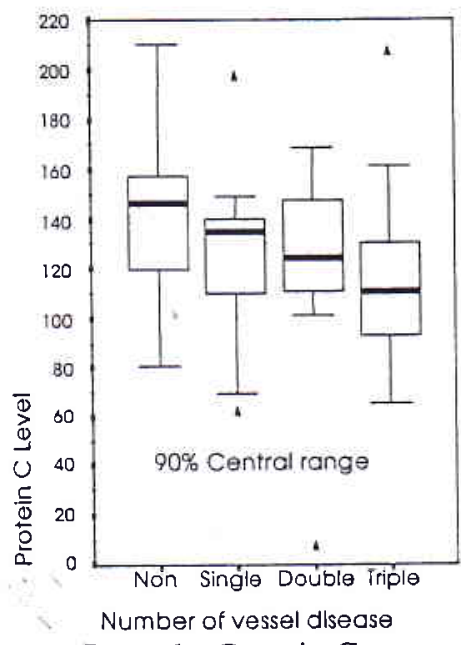

Box-plot Protein C

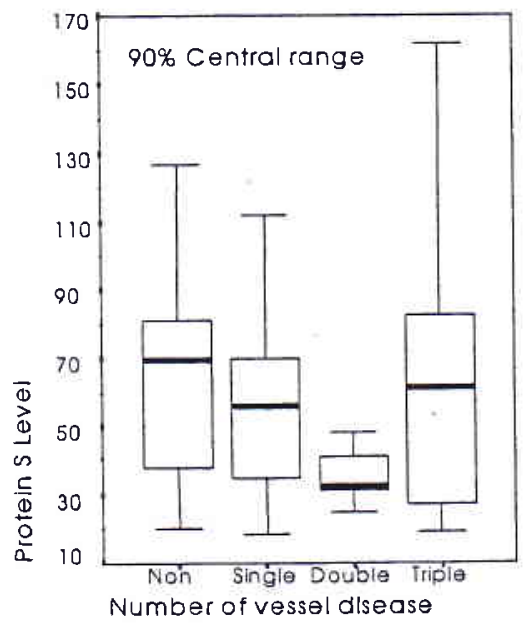

Box-plot Protein S

Figure 1. Box and whisker plot of $90 \%$ central range frequency on AT III, protein C, and protein S activity according to the number of vessels disease.

Table 2. The frequency distribution of AT III, protein $\mathrm{C}$ and protein $\mathrm{S}$ according to the number of vessel disease (VD).

\begin{tabular}{|c|c|c|c|c|c|c|}
\hline \multirow{3}{*}{$\begin{array}{c}\text { Number } \\
\text { of } \\
\text { VD }\end{array}$} & \multicolumn{2}{|c|}{ AT III } & \multicolumn{2}{|c|}{ Protein C } & \multicolumn{2}{|c|}{ Protein S } \\
\hline & $>75 \%$ & $<75 \%$ & $>70 \%$ & $<70 \%$ & $>70 \%$ & $<70 \%$ \\
\hline & & & & & & \\
\hline 0 & $28(93,3 \%)$ & $2(6,7 \%)$ & $30(100 \%)$ & 0 & $15(50 \%)$ & $15(50 \%)$ \\
\hline 1 & $8(88,9 \%)$ & $1(11,1 \%)$ & $7(77,8 \%)$ & $2(22,2 \%)$ & $3(33,3 \%)$ & $6(66,7 \%)$ \\
\hline 2 & $7(100 \%)$ & 0 & $6(85,7 \%)$ & $1(14,3 \%)$ & 0 & $7(100 \%)$ \\
\hline 3 & $8(57,1 \%)$ & $6(42,9 \%)$ & $13(92,9 \%)$ & $1(7,1 \%)$ & $5(35,7 \%)$ & $9(64,3 \%)$ \\
\hline Total & $23(76,7 \%)$ & $7(23,3 \%)$ & $26(86,7 \%)$ & $4(13,3 \%)$ & $8(26,7 \%)$ & $22(73,3 \%)$ \\
\hline
\end{tabular}


Both AT-III and protein $\mathrm{C}$ had significant correlations with the number of vessel disease, as shown in Table 3. There was no correlation between protein S activity and the number of vessel disease or level of AT-m, or level of protein $\mathrm{C}$ (Table 3 ).

According to the definition, AT-III deficiency refers to below $75 \%$, while protein $\mathrm{C}$, or protein $\mathrm{S}$ deficiency refers to below $70 \%$. The discriminant analysis on the frequency of distribution of AT-III, protein $\mathrm{C}$, and protein $\mathrm{S}$ deficiency demonstrated that protein $\mathrm{C}$ deficiency posed a greater risk ACS than AT-III deficiency. Protein S deficiency apparently was a reinforcing factor on AT-III deficiency for ACS while AT-III deficiency without protein $S$ deficiency did not pose a significant risk.

On linear regression analysis with the number of vessels disease as a dependent variable, and the activity of AT-III as an independent variable, the activity of AT III has a determinant coefficiency of $13,25 \%$ in contributing to ACS. The expected activity of AT-III that poses a risk of single vessel disease is $\leq 45 \%$, and to triple vessel disease if activity of AT-III is $\leq 9,5 \%$. With the activity of protein $\mathrm{C}$ as an independent variable, the activity of protein $C$ has a determinant coefficiency of $9,06 \%$ in contributing to the development of ACS.

Logistics regression analysis by backward method were performed using vessel disease as a dependent variable and AT-III, protein C, and AT-III by protein
$\mathrm{C}$ interaction as an independent variables entered in step one, as well as similar model with AT-III, protein $\mathrm{S}$, and AT-II by protein $S$ interaction as independent variables entered in step one. On both analysis AT-III posed a significant risk of ACS. These analysis showed that protein $\mathrm{S}$ had no specific correlation with the development of ACS.

From the same analysis by backward method with vessel disease as a dependent variable and protein $C$, protein $S$, and protein $C$ by protein $S$ interaction as independent variables entered in step one, protein $C$ posed a significant risk of ACS. This analysis also showed that, protein $S$ had no specific correlation with the development of ACS. With double and triple vessel disease as dependent variables, and protein $C$, protein $S$, and protein $C$ by protein $S$ interaction as independent variables are entered in step one, protein $\mathrm{C}$ posed a significant risk of ACS. From this analysis, protein $S$ also demonstrated no specific correlation to the development ACS

From the analysis by backward method with double and triple vessel disease as dependent variables, and AT-III, protein S, and AT-III by protein $S$ interaction as independent variables entered in step one, AT-III by protein $S$ interaction posed a significant risk of ACS. This analysis demonstrated that protein $S$ had no specific correlation with the development of ACS, instead might have acted as a reinforcing factor on AT III deficiency to the development of ACS.

Table 3. Pearson correlations matrix on the number of vessel disease, activity of AT-III, protein C, and protein $S$

\begin{tabular}{cccccc}
\hline & & Number of VD & AT III & Protein C & Protein S \\
\hline $\begin{array}{c}\text { Number of vessel } \\
\text { disease (VD) }\end{array}$ & Correlation & 1 & $-\mathbf{0 , 3 6 4}$ & $\mathbf{- 0 , 3 0 1}$ &,- 0029 \\
& $P$ (2-tailed) & & $\mathbf{0 , 0 0 4}$ & $\mathbf{0 , 0 2 0}$ & 0,824 \\
\hline \multirow{2}{*}{ AT III } & Correlation & $\mathbf{- 0 , 3 6 4}$ & 1 & $\mathbf{0 , 4 5 9}$ & $-0,022$ \\
& $p$ (2-tailed) & $\mathbf{0 , 0 0 4}$ & & $\mathbf{0 , 0 0 0}$ & 0,867 \\
\hline \multirow{2}{*}{ Protein C } & Correlation & $\mathbf{- 0 , 3 0 1}$ & $\mathbf{0 , 4 5 9}$ & 1 & $-0,067$ \\
& $p$ (2-tailed) & $\mathbf{0 , 0 2 0}$ & $\mathbf{0 , 0 0 0}$ & & 0,613 \\
\hline \multirow{2}{*}{ Protein S } & Correlation & $-0,029$ & $-0,022$ & $-0,067$ & 1 \\
& $P$ (2-tailed) & 0,824 & 0,867 & 0,613 & \\
\hline
\end{tabular}




\section{DISCUSSION}

Pathophysiologic mechanisms that can trigger onsets of acute coronary syndromes are: (a) Thrombosis, occurring on previously coronary endothelial pertubations or "disrupted or intact plaques", when systemic thrombotic tendency is high because of platelet activation, a hypercoagulability state, and/or impaired fibrinolysis system; (b) Plaque disruption; the risk of plaque disruption depending more on plaque composition and vulnerability (plaque type) than on degree of stenosis (plaque size). Major determinants of vulnerability of plaque rupture are size and consistency of atheromatous core, and ongoing inflammation within the cap. ${ }^{7,8}$ (c) Vasoconstriction, generalized or occurring local around a coronary plaque. In coronary thrombosis, three aspect of the haemostatic system leading to fibrin formation associated with the onset of ischaemic heart disease (IHD), are: (1) Hyperfunction of platelets, leading to the release of Platelet Factor-2 (PF2) causing fibrinogen activation, PF3 causing prothrombin complex activation, and PF4 as an anti-heparin factor; (2) High levels of: (a) Factor VIlc, VIIIa, and vWF leading to thrombin formation; (b) Fibrinogen; (c) Inhibitor to plasminogen activating factor; (3) Functional deficiency of AT III, protein $\mathrm{S}$, and protein $\mathrm{C}$.

Hypercoagulability state is a condition of high serum levels of peptide materials, an F1 and F2 fragment of prothrombin, where endothelial perturbation and deficiency in one or both hemostatics control and fibrinolytics system lead to thrombosis. Thrombomodulin released by endothelial cells activate AT III, and protein $\mathrm{S}$ binding protein $\mathrm{C}$, are the main mechanisms of hemostatics control, and plasminogen activators are the main mechanisms of fibrinolytic system.

Potential defense mechanisms against thrombosis include AT III found a gradient increasing level from those at low risk of ischemic heart disease. Meade ${ }^{4}$ reported AT-III activity were positively correlated with VIIc and fibrinogen. In contrast, low activity were found in those with a history infarction or other manifestations of arterial disease. Such low activity was associated with increased incidence of major thrombotic episodes, similar to that found in this study, with the exclusion of protein $\mathrm{S}^{4,9}$

On patients of presenting with the first episode of thrombosis, the incidence of AT III deficiency was slightly higher (1,29-1,5 times) than in protein $C$ deficiency, ${ }^{4}$ which was no different in this study, where AT III and protein C deficiency contributed as determinants to the development of ACS $13,25 \%$ and $9,06 \%$ ( 1,46 times) respectively. AT III activity below $50 \%$ are prognostic to thrombosis ${ }^{2}$ near the level of AT III activity expected to contibute to the development of ACS in this studiy. Innerfield I et al. ${ }^{9}$ reported 2 out of $23(8,7 \%)$ control subject with AT-III deficiency whics was nearly equal with our studies, where $6,7 \%$ control subjects had AT-III deficiency. However, in subjects with ACS 22 out of $24(91,7 \%)$ suffered from AT-II deficiency which differ from our studies, where only $23,3 \%$ are AT-Ш deficient.

Protein $\mathrm{C}$ deficiency is usually classified into two types: ${ }^{3}$ type I is characterized by reduced antigenic levels and functional activity in degrading activated factors Vc and VIIIc, while type II is characterized by normal antigenic levels with reduced functional activity in degrading activated factors Vc and VIIIc. Both types are associated with a thrombophilic state.

AT III deficiency is commonly divided into three types: ${ }^{3}$ type I is quantitative deficiency, type II is qualitative abnormal ability to inactivate factor $\mathrm{Xa}$ and thrombin, type III is due to mutation that reduces the ability of AT III to bind with heparin. In the last two types of AT UI deficiency, AT III activity may in normal limits. That explains AT III deficiency can not be ascertained solely from activity levels. Instead, what it is the most important to asses AT III effectiveness in inactivating factor $\mathrm{Xa}$ and thrombin. Cases with normal or high level AT III activity may have deficient function. In contrast, in control subjects, low-level activity of AT III may be effective in inactivating factor $\mathrm{Xa}$ and thrombin. This also explains why low levels of protein $\mathrm{C}$ posed a greater risk of ACS than low levels of AT III.

Protein S function in hemostatics is a cofactor for the anticoagulant effect of protein $C$. In the circulation approximately $60 \%$ of protein $\mathrm{S}$ is bound to $\mathrm{C} 4 \mathrm{~b}$ binding protein, while the remainder are free (unbound) or bound to protein $\mathrm{C}^{3}$. Low level activity of total protein $\mathrm{S}$ may or may not involve protein $\mathrm{S}$ binding to protein C. That explains why low-levels of only protein $\mathrm{S}$ did not contribute much to development of ACS. Protein $\mathrm{S}$ binding protein $\mathrm{C}$ assay were more valid than total activity assay in determining the risk in the development ACS. In this study, where protein 
S activity level were the total level, out of 29 subjects protein $S$ deficiency alone was not a significant risk for ACS. On the other hand, AT III deficiency, all of them did not have activity below $50 \%$ or below $45 \%$. However in subjects with protein $\mathrm{S}$ deficiency, there was a significant risk for ACS. This fact suggests that protein $S$ deficiency is a reinforcing factor on AT III deficiency to the development of ACS.

\section{CONCLUSION}

Protein C and AT III deficiency could trigger ACS with determinant coefficients of $9,06 \%$ and. $13,25 \%$ respectively. Low-level activity of protein $\mathrm{C}$ posed a greater risk for ACS than low-level activity of AT III. Protein $S$ deficiency was a reinforcing factor on ATIII deficiency for ACS. The cut-off point activity of AT-III without protein $S$ deficiency expected to contribute single vessel disease is $45 \%$, and $9,5 \%$ to triple vessel disease.

\section{REFERENCES}

1. Bick RL, Kaplan H. Syndromes of thrombosis and hypercoagulability. Congenital and acquired causes of thrombosis. Med Clin North Am 1998;82:409-58.

2. National house hold survey on health-Department of Health, Indonesia 1992.

3. Ginsberg J at al, Eds. Critical Decisions in Thrombosis and Hemostasis. London, BC Decker Inc. Hammilton. 1998

4. Meade TW, Cooper J, Miller GJ, Howartt DJ, Striling Y. Antithrombin III and arterial disease. Lancet 1991:338.

5. The Joint European Society of Cardiology/American College of Cardiolugy Committee. Myocardial infarction redefined-A consensus document of The Joint European Society of Cardiology/American College of Cardiology Committee for the Redefinition of Myocardial Infarction. Eur Heart J 2000;21:1502-13.

6. Braunwald E. Unstable angina : a classification. Circulation 1989;80:410-4

7. Falk E, Shah PK, Fuster V. Coronary plaque disruption. Circulation 1995;92:657-71.

8. Shah PK. New insight into the pathogenesis and prevention of acute coronary syndrome. Am J Cardiol 1997;79(12B):17-23.

9. Innerfield I, Goldfischer JD, Reiss HR, Greenberg J. Serum antithrombin in coronary-artery disease. Am J Clin Pathol 1976;6:64-8 